\title{
Conjecturing Ability Dalam Pembelajaran Daring Masa Pandemi Covid-19
}

\author{
Yani Supriani ${ }^{1,}$ Giyanti $^{2}$, Tb. Sofwan Hadi $^{3}$ \\ ${ }_{1,2,3}$ Pendidikan Matematika, Universitas Serang Raya, Banten \\ *yani.supriani2@gmail.com
}

\begin{abstract}
Abstrak
Dalam masa pandemi Covid-19 pembelajaran dilakukan secara daring sehingga menghambat dalam mengembangkan kemampuan-kemapuan kognitif matematis, padahal kemampuan ini merupakan penunjang kecakapan siswa dalam mempelajari matematika. Salah satu kemampuan kognitif yang dikembangkan adalah conjecturing ability atau kemampuan memformulasikan konjektur matematis siswa sekolah menengah pertama (SMP). Konjektur adalah alasan kenapa seseorang memiliki suatu keyakinan, sebuah penjelasan mengenai kenapa sebuah keyakinan adalah benar, atau bagaimana seseorang tahu apa yang diketahuinya. Sehingga perlu dilakukan kajian mendalam serta analisis yang terhadap conjecturing ability atau kemampuan konjektur matematis siswa. Dalam penelitian ini melibatkan subjek sebanyak 26 siswa di salah satu sekolah menengah pertama di Kota Serang, pendekatan yang digunakan dalam penelitian ini adalah pendekatan kualitatif. Hasil dari penelitian ini conjecturing ability atau kemampuan konjektur masih tergolong kurang baik pada kategori kemampuan siswa dalam membuat bukti terhadap solusi. Sehingga diberikan perbaikan dari masih kurangnnya conjecturing ability atau kemampuan konjektur matematis siswa.
\end{abstract}

Kata kunci: Conjecturing Ability; Kemampuan Kognitif; Pembelajaran Daring.

\begin{abstract}
Learning was done online during the COVID-19 pandemic; it inhibits the development of mathematical cognitive abilities, whereas this ability supports the learning skills of students in mathematics. One of the cognitive gained is the conjecturing ability or the ability to formulate the mathematical conjecture of junior high school students. The conjecture is the reason that someone has a belief, interpretation of why a belief is true, or how someone knows what he knows. So it is necessary to do an in-depth study and analysis of students' mathematical conjecturing abilities. This study involved 26 students in one of junior high school in Serang as the research subjects, the approach used is a qualitative approach. The finding shows that the students' conjecturing ability is still worse in the category of students' ability in making evidence to the solution, so it needs improvement from the poor of students' mathematical conjecturing abilities.
\end{abstract}

Keywords: Conjecturing Ability, Cognitive Ability, Online Learning.

\section{PENDAHULUAN}

Belajar secara daring tentu bukan hal yang mudah bagi siswa (Gillett-Swan, 2017). Kesulitan muncul bukan hanya perkara keterampilan peng-gunaan teknologi, tetapi juga terkait dengan beban kerja yang besar mengingat ada banyak mata pelajaran yang harus dihadapi dalam masa pandemi COVID-19 ini. Hal ini terjadi karena siswa terbiasa dengan pembelajaran tatap muka secara reguler, sedangkan pembelajaran jarak jauh sebelumnya hanya dilakukan secara insidental (Rahardjo, Qomariyah, Mulyani, \& Andriani, 2020). 
Setyosari (2015) menyatakan bahwa pembelajaran melalui jaringan memiliki potensipotensi, antara lain : kebermaknaan belajar, kemudahan mengakses, dan peningkatan hasil belajar. Dalam konteks belajar secara online, mahasiswa dapat berhubungan secara cepat dan langsung dengan teks, gambar, suara, data, dan video dua arah, dengan bimbingan pengajar. Secara tidak langsung di masa pandemi ini juga merupakan aplikasi sepenuhnya dari industri digital 4.0 yang memang dikembangkan oleh pemerintah. Akan tetapi karena ini hal baru dalam proses pembelajaran maka perlu dikembangkan lagi.

Dengan demikian proses belajar mengajar secara daring, dapat dikembangkan dengan memperkaya pengalaman yang bermakna melalui kemampuan kognitif (Hewi \& Asnawati, 2020). Kemampuan kognitif tentu harus dikembangkan karen apada dasarnya manusia adalah makhluk yang memiliki kemampuan untuk berpikir, sehingga melalui kemampuan itulah manusia dapat memperoleh pengetahuan dan meninggalkan makhluk lain ciptaan Tuhan (Supriani, Fardillah, \& Herman, 2019). Secara umum, berpikir didefinisikan sebagai suatu kegiatan mental untuk memperoleh pengetahuan.

Dalam mendapatkan pengetahuannya, manusia dewasa ini melakukannya dengan cara ilmiah yakni memahami masalah, merumuskan hipotesis, mengumpulkan data, menguji hipotesis dan merumuskan kesimpulan (Sanjaya, 2011). Kegiatan ilmiah ini terdapat dalam conjecturing ability atau kemampuan konjektur yang merupakan salah satu kemampuan kognitif yang menekankan pada praduga dalam pemecahan masalah yang kemudian dapat ditarik kesimpulan dan pengambilan keputusannya (Supriani \& Sholahudin, 2019).

Conjecturing Ability atau Konjektur adalah alasan kenapa seseorang memiliki suatu dugaan, keyakinan, sebuah penjelasan mengenai kenapa sebuah keyakinan adalah benar, atau bagaimana seseorang tahu apa yang diketahuinya. Pembenaran juga berarti melakukan pertanggungjawaban rasional atas klaim kebenaran kepercayaan atau pendapat yang dipegang. Dalam mengajar Matematika di sekolah, conjecturing ability atau kemampuan konjektur matematis merupakan suatu kebutuhan yang harus diaplikasikan dalam pembelajaran sehingga siswa dapat memiliki keterampilan dan menerapkannya dalam kehidupan sehari-hari sehingga meningkatkan hasil belajar.

Berawal dari De Villiers (1990) menggunakan istilah pembuktian untuk menjelaskan tentang conjecturing ability atau kemampuan konjektur. Namun Staples \& Bartlo (2010) memperluasnya dengan istilah conjecturing ability atau konjektur, karena pembuktian merupakan bentuk spesifik dari konjektur. Menurut mereka conjecturing ability atau konjektur digunakan untuk melakukan validasi terhadap sebuah penyataan, menghasilkan wawasan terhadap suatu fenomena, dan sistematisasi pengetahuan. Semakin berhati-hati 
seseorang mengevaluasi suatu pernyataan dan semakin maksimal memisahkan isu-isu yang relevan dan yang tidak relevan, maka akan semakin kritis pemikiran orang tersebut. Jadi conjecturing ability atau konjektur matematis membutuhkan keterampilan termasuk kemampuan untuk mendengarkan dan membaca secara hati-hati, mencari dan menemukan asumsi-asumsi tersembunyi, dan menyelidiki konsekuensi-konsekuensi dari suatu pernyataan.

Conjecturing ability atau Konjektur matematis telah menjadi salah satu alat yang digunakan dalam kehidupan sehari-hari kita untuk memecahkan beberapa masalah karena melibatkan penalaran logis, menafsirkan, menganalisis dan mengevaluasi informasi untuk memungkinkan satu mengambil handal dan keputusan valid. Conjecturing ability atau Konjektur matematis adalah kemampuan untuk membuat pernyataan metematika yang bernilai benar berdasarkan observasi, investigasi, eksplorasi, eksperimen, dan inkuiri. Kebenaran pernyataan tersebut belum dibuktikan kebenarannya secara formal (umum), akan tetapi baru bersifat tidak formal dengan contoh atau gambar. Indikator kompetensi konjektur adalah indikator-indikator pada kemampuan observasi, investigasi, eksplorasi, dan inkuiri (Lestari \& Yudhanegara, 2015).

Back, Mannila, \& Wallin (2010), menjelaskan bahwa peran conjecturing ability atau konjektur dalam membangun kecakapan Matematika setidaknya meliputi tiga aspek, yakni penalaran matematis, pemahaman konsep Matematika yang mendalam dan komunikasi matematis. Dalam aspek penalaran matematis Kilpatrick et al. (dalam Brodie, 2010) menyatakan bahwa conjecturing ability atau kemampuan menkonjektur merupakan elemen yang penting dalam penalaran adaptif, karena melakukan konjektur berarti memberikan penalaran yang cukup jelas. Mereka berpendapat bahwa siswa perlu memiliki kemampuan menkonjektur dan menjelaskan suatu gagasan agar penalaran mereka menjadi jelas, sehingga kemampuan penalaran mereka terasah dan meningkatkan pemahaman konseptual.

Aspek pemahaman konsep conjecturing ability atau konjektur matematis tidak hanya berfungsi untuk meyakinkan orang lain terhadap jawaban yang kita buat. Tetapi juga untuk memperdalam pemahaman konsep Matematika. Hasil penelitian Lo, Grant, \& Flowers (2008) juga menunjukkan bahwa siswa mengalami peningkatan pemahaman terhadap konsep Matematika ketika diajarkan dengan menggunakan strategi konjektur. Dalam artikelnya mereka menyatakan bahwa pemahaman siswa terhadap sebuah konsep Matematika yang mendalam diduga mampu meningkatkan conjecturing ability atau kemampuan konjektur. Sehingga berdampak pada ketidakmampuan siswa dalam menjelaskan apa yang 
dipikirkan senantiasa dikaitkan dengan pemahaman siswa yang kurang lengkap terhadap soal yang dihadapi.

Aspek komunikasi matematis, conjecturing ability atau konjektur memiliki peran untuk menjelaskan mengenai sebuah keyakinan adalah benar. Pembenaran juga berarti melakukan pertanggungjawaban rasional atas klaim kebenaran kepercayaan atau pendapat yang dipegang. Berdasarkan NCTM (2008), siswa pada setiap tingkatannya seharusnya memiliki kemampuan untuk mengomunikasikan gagasan matematisnya, menganalisa gagasan siswa lain, menggunakan bahasa Matematika secara tepat, mengembangkan dan mengevaluasi argumen dan pembuktian matematis. Conjecturing ability atau Konjektur juga memerlukan kemampuan komunikasi matematis.

Aspek kemampuan konjektur dalam penelitian ini, sebagai berikut: a) Kemampuan menyelidiki kasus secara utuh Siswa dapat menyelidiki sebuah gambar untuk menentukan garis apa saja yang sejajar, b) Kemampuan melakukan manipulasi matematik Siswa dapat menentukan luas daerah yang tidak beraturan dengan bangun-bangun yang beraturan, c) Kemampuan menentukan pola untuk membuat generalisasi Siswa dapat menentukan pola luas bangun datar dengan membagi menjadi beberapa bagian bangun datar, d) Kemampuan melakukan pembuktian Siswa dapat menemukan suatu formula luas dan keliling dari bangun layang-layang yang tidak diketahui secara langsung (NCTM, 2008).

Dengan demikian penelitian ini untuk melihat dan mengetahui pengembangan dalam upaya meningkatkan conjecturing ability atau kemampuan konjektur matematis siswa melalui pembelajran daring di masa pandemi covid-19 ini.

\section{METODE}

Penelitian ini mengunakan pendekatan kualitatif, dimana parisipan atau subjek sebanyak 26 siswa sekolah menengah pertama di salah satu sekolah di Kota Serang. Soal yang diberikan kepada siswa sebanyak empat soal yang bertujuan untuk mengembangkan kemampuan konjektur matematis siswa pada materi garis sudut dan bangun datar. Siswa diminta menjawab soal tersebut dalam bentuk uraian. Kemudian jawaban siswa dianalisis konten, melalui prosedural dan konseptual dalam menjawab soal. Pengambilan data dengan memberikan soal yang terdiri dari empat soal yang berkaitan dengan kemampuan konjektur. Dari jawaban siswa diperoleh data yang berupa jawaban yang bersifat deskriptif tentang kemampuan konjektur matematis siswa.

Tahapan penelitian ini terbagi dalam tiga tahapan, yaitu: (1) Tahap pra lapangan, (2) Tahap pekerjaan lapangan, dan (3) Tahap analisis data. Pada tahap pra lapangan, peneliti 
melakukan observasi serta meminta izin pada pihak sekolah dan melakukan penyusunan instrument kemampuan konjektur matematis. Pada tahap pekerjaan lapangan peneliti memberikan soal yang berupa tes kemampuan konjektur matematis siswa. Sedangkan pada tahap analisis data, peneliti akan melakukan analisis hasil tes kemampuan konjektur matematis siswa.

Pada materi sudut, garis dan bangun datar yang terdiri dari empat soal kemampuan konjektur siswa sebagai berikut: (1) Melalui ilustrasi siswa mampu membentuk sudut sikusiku siswa mampu memberikan kesimpulan bahwa jumlah semua sudut dalam gambar tersebut sama besar dengan sudut siku-siku, (2) Siswa mampu menyusun jenis sudut yang sama terlebih dahulu untuk menentukan besaran sudut-sudut yang ditanyakan, (3) Siswa mampu membuktikan beberapa sudut yang sehadap sehingga dapat membandingkan besaran luas dari bangun datar yang terdapat pada gambar, (4) Siswa mampu menentukan pengetahuan prasyarat mana yang harus digunakan untuk memahami dan menyelesaikan luas persegi panjang yang trdapat dalam segitiga sama kaki. Soal - soal ini bertujuan untuk memungkinkan siswa dalam menarik kesimpulan, menyusun bukti, membuat bukti terhadap solusi dan membuat keputusan.

Data yang telah diperoleh, selanjutnya dianalisis melalui tiga kriteria jawaban, yaitu: (1) Jawaban benar, (2) Jawaban salah, (3) Tidak menjawab. Data yang telah diperoleh kemudian dikelompok kan berdasrkan aspek konjektur matematis, yang disajikan dalam bentuk tabel.

\section{HASIL PENELITIAN}

Pada tabel 1 disajikan rekapitulasi jawaban kemampuan konjektur matematis siswa pada materi sudut, garis dan bangun datar, sebagai berikut.

Tabel 1. Jawaban Konjektur Siswa

\begin{tabular}{lllccc}
\hline No & $\begin{array}{l}\text { Aspek Konjektur } \\
\text { Matematis }\end{array}$ & \multicolumn{1}{c}{ Indikator } & $\begin{array}{c}\text { Jawaban } \\
\text { Benar }\end{array}$ & $\begin{array}{c}\text { Jawaban } \\
\text { Salah }\end{array}$ & $\begin{array}{c}\text { Tidak } \\
\text { Menjawab }\end{array}$ \\
\hline 1. & $\begin{array}{l}\text { Kemampuan } \\
\text { menyelidiki kasus } \\
\text { secara utuh }\end{array}$ & $\begin{array}{l}\text { Siswa dapat menyelidiki } \\
\text { sebuah gambar untuk } \\
\text { menentukan garis apa saja } \\
\text { yang sejajar. }\end{array}$ & 5 & 11 & 10 \\
\hline 2. & $\begin{array}{l}\text { Kemampuan } \\
\text { melakukan } \\
\text { manipulasi } \\
\text { matematik }\end{array}$ & $\begin{array}{l}\text { Siswa dapat menentukan luas } \\
\text { daerah yang tidak beraturan } \\
\text { dengan bangun-bangun yang } \\
\text { beraturan. }\end{array}$ & 6 & 18 & 2 \\
\hline $\begin{array}{l}\text { Kemampuan } \\
\text { menentukan pola } \\
\text { untuk membuat }\end{array}$ & $\begin{array}{l}\text { Siswa dapat menentukan pola } \\
\text { membagi menjadi beberapa } \\
\text { meman datar dengan }\end{array}$ & 8 & 6 & 12 \\
\hline
\end{tabular}




\begin{tabular}{lllccc}
\hline No & $\begin{array}{l}\text { Aspek Konjektur } \\
\text { Matematis }\end{array}$ & \multicolumn{1}{c}{ Indikator } & $\begin{array}{c}\text { Jawaban } \\
\text { Benar }\end{array}$ & $\begin{array}{c}\text { Jawaban } \\
\text { Salah }\end{array}$ & $\begin{array}{c}\text { Tidak } \\
\text { Menjawab }\end{array}$ \\
\hline 4. & $\begin{array}{l}\text { Keneralisasi } \\
\text { memampuan } \\
\text { pelakukan }\end{array}$ & $\begin{array}{l}\text { bagian bangun datar } \\
\text { formula dapat menemukan suatu } \\
\text { bangun layang-layang yang } \\
\text { tidak diketahui secara } \\
\text { langsung. }\end{array}$ & 6 & 5 & 15 \\
\hline
\end{tabular}

Berdasarkan tabel 1 maka persentase jawaban kemampuan konjektur siswa digambarkan melalui Diagram Batang 1 sebagai berikut:

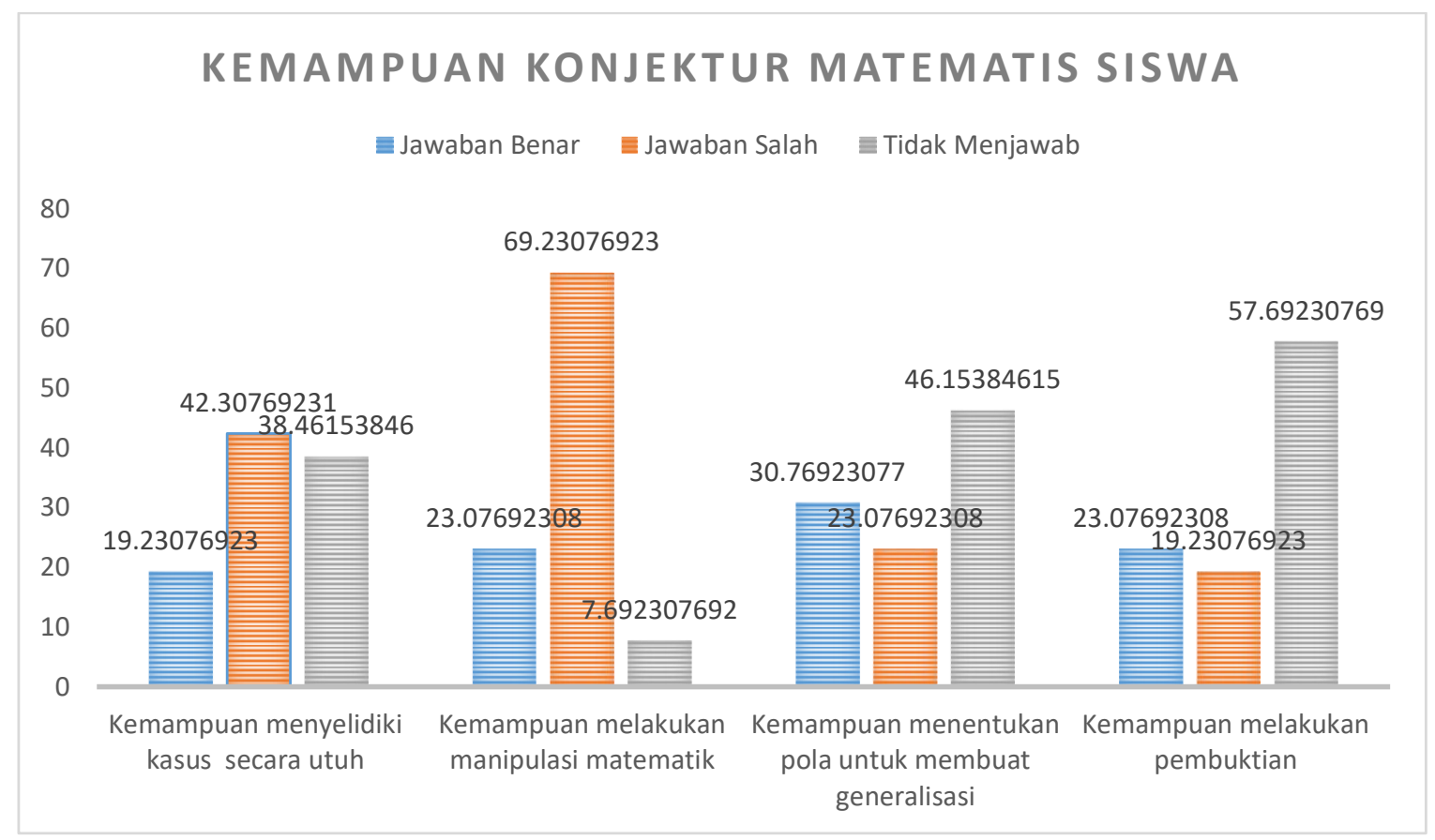

Diagram 1. Diagram Batang Kemampuan Konjektur Matematis Siswa

\section{PEMBAHASAN}

Berdasarkan diagram batang 1, maka pada aspek kemampuan menyelidiki kasus secara utuh 19\% siswa yang mampu menjawab, $42 \%$ siswa yang menjawab salah dan $39 \%$ siswa yang tidak menjawab soal. Pada aspek kemampuan melakukan manipulasi matematik siswa yang menjawab benar sebanyak 23\%, dengan $69 \%$ siswa yang menjawab salah, serta $8 \%$ siswa yang tidak memberikan jawaban. Pada aspek kemampuan menentukan pola membuat bukti terhadap solusi dan generalisasi, $31 \%$ siswa menjawab benar, $23 \%$ siswa menjawab salah dan $46 \%$ siswa tidak menjawab soal. Aspek kemampuan melakukan pembuktian 23\% siswa menjawab benar, $19 \%$ siswa menjab salah, dan 58\% siswa tidak memberikan jawaban. Berdasarkan persentase ini terlihat dengan jelas, bahwa kemampuan konjektur matematis siswa masih kurang baik. Namun pada aspek kemampuan menarik kesimpulan sebanyak $42 \%$ 
dan 69\% aspek menyusun bukti siswa memberikan jawaban, namun salah. Hal ini membuktikan bahwa siswa masih perlu dilatih serta di tingkatkan kemampuan menarik kesimpulan dan menyusun bukti. Hal yang sangat tidak baik terlihat pada aspek kemampuan membuat bukti terhadap solusi dan membuat keputusan, sebanyak $46 \%$ siswa pada aspek membuat bukti terhadap solusi dan 58\% siswa pada aspek membuat keputusan tidak memberikan jawaban.

Pada kemampuan konjektur matematis siswa zone of proximal development (ZPD) perlu dikembangkan, yaitu dengan bantuan orang lain, melalui guru (tutor), teman sebaya serta lingkungan yang dapat mengembangkan kemampuan tersebut. Vygotsky (1962) mengemukakan bahwa "the distance between the actual developmental level as determined by independent problem solving and the level of potential development as determined through problem solving under adult guidance, or in collaboration with more capable peers". Sehingga dalam mengembangkan kemampuan konjektur peranan pembimbing maupun lingkungan sangat diperlukan.

Vygotsky (1962) menjelaskan bahwa membangun pengetahuan siswa tidak bisa dipisahkan dari konteks sosial dan budaya, sehingga untuk mengeksplorasi kemampuan konjektur matematis siswa adalah dengan memahami perkembangan mental siswa, lingkungan belajar siswa serta bantuan kognitif secara bertahap dari guru. Vygotsky (Cole, 1997) mengigatkan bahwa interaksi social menjadi factor yang paling utama dalam membentuk perkembangan psikologis siswa dalam belajar. Sejalan dengan Vygotsky (Roosevelt, 2008) "the main goal of education from Vygotskian perspective is to keep learners in their own ZPDs as often as possible by giving them interesting and culturally meaningful learning and problem-solving tasks that are slightly more difficult than what they do alone, such that they will need to work together either with another, more competent peer or with a teacher or adult to finish the task".

Berdasarkan data deskriptif serta teori dan temuan tersebut, memberikan indikasi bahwa kemampuan konjektur matematis siswa masih kurang baik. Hal tersebut memberikan indikasi, bahwa perlunya dilakukan penelitian lanjutan untuk memberikan solusi dari kurangnya kemampuan konjektur siswa. Kurang baiknya kemampuan konjektur matematis siswa pada penelitian ini disebabkan oleh beberapa faktor, yaitu: (1) Siswa belum terbiasa menyelesaikan soal - soal kemampuan konjektur secara spesifik, (2) Siswa mengalami kesulitan dalam membuktikan beberapa sudut yang sehadap sehingga dapat membandingkan besaran luas dari bangun datar yang terdapat pada gambar dan membuat keputusan pada soal yang diberikan, (3) Siswa banyak mengalami kekeliruan pada soal ilustrasi yang membentuk sudut siku-siku 
siswa mampu memberikan kesimpulan bahwa jumlah semua sudut dalam gambar tersebut sama besar dengan sudut siku-siku dan siswa keliru dalam menyusun jenis sudut yang sama terlebih dahulu untuk menentukan besaran sudut-sudut yang ditanyakan. Namun kemampuan konjektur matematis siswa tidak dalam keadaan kosong, siswa sudah memiliki kemampuan konjektur matematis, hanya saja kemampuan tersebut belum dikembangkan dengan baik. Dimana zone of proximal development (ZPD) siswa sudah terbentuk sebelumnya.

\section{SIMPULAN}

Tidak dapat dipungkiri penggunaan sistem belajar online merupakan suatu yang relatif mahal, namun dapat ditarik suatu manfaat yang sangat besar dari strategi tersebut baik bagi peserta didik maupun bagi pendidik. Mahalnya pembelajaran online juga masih bisa terjangkau menggantikan biaya transportasi ketika harus datang ke kelas, dengan pandangan demikian maka sudah seharusnya para pendidik untuk tetap memperhatikan kemampuankemampuan matematis yang harus dimiliki siswa untuk meningkatkan kecakapan dan pemahaman matematisnya, salah satunya adalah conjecturing ability atau kemampuan konjektur dimana secara tidak langsung meskipun siswa mendapatkan materi dari pendidik, akan tetapi karena tidak tatap muka maka dalam menyelesaikan permasalahan matematika langkah pertama yang akan dilakukan adalah menduga terlebih dahulu dari permasalahan tersebut, kemudian dapat menarik kesimpulan serta melakukan pengambilan keputusan dari pemecahan masalah secara matematisnya. Oleh karena itu ability conjecturing atau kemampuan konjektur perlu ditingkatkan oleh setiap siswa.

\section{REFERENSI}

Back, J.R., Mannila, L. \& Wallin, S. (2010). Student Justifications In High School Mathematics. Proceedings of the Sixth Congress of the European Society for Research in Mathematics Education, 291-300. https://pdfs.semanticscholar.org/3320/5b6705c 524c17c18ef505d28457c6d735568.pdf\#page $=373$

Brodie, K. (2010). Teaching Mathematical Reasoning in Secondary School Classrooms. New York: Springer.

Cole, M. (1997). Cultural Psychology: A Once and Future Discipline. Cambridge: The Belknap Press of Harvard University.

De Villiers, M. D. (1990). The role and function of proof in mathematics. Pythagoras, 24, (1) 17-24. 
Gillett-Swan, J. (2017). The Challenges of Online Learning: Supporting and Engaging the Isolated Learner. Journal of Learning Design, 10(1), 20. Doi : https://doi.org/10.5204/jld.v9i3.293

Hewi, L., \& Asnawati, L. (2020). Strategi Pendidik Anak Usia Dini Era Covid-19 dalam Menumbuhkan Kemampuan Berfikir Logis. Jurnal Obsesi : Jurnal Pendidikan Anak Usia Dini, 5(1), 158-167. Doi : https://doi.org/10.31004/obsesi.v5i1.530

Lestari, Y. (2015). Penelitian Pendidikan Matematika. Bandung: PT. Refika Aditama.

Lo, J. J., Grant, T. J., \& Flowers, J. (2008). Challenges in deepening prospective teachers' understanding of multiplication through justification. Journal of Mathematics Teacher Education, 11(1), 5-22.

NCTM. (2008). Standards for School Mathematics. Reston: NCTM.

Rahardjo, W., Qomariyah, N., Mulyani, I., \& Andriani, I. (2020). Social media fatigue pada mahasiswa di masa pandemi COVID-19: Peranneurotisisme, kelebihan informasi , invasion of life , kecemasan, dan jenis kelamin. Jurnal Psikologi Sosial, 18(59). Doi : https://doi.org/10.7454/jps.2020.xx

Roosevelt F.D. (2008). Zone of Proximal Development. Encyclopedia of Educational Psychology. SAGE publication.

Staples, M., Bartlo, J., \& Staples, M. (2010). Justification as a learning practice: Its purposes in middle grades mathematics classroom. CRME Publications, 3(1), 1-9. https://opencommons.uconn.edu/merg_docs/3

Sanjaya, W. (2011). Strategi Pembelajaran Berorientasi Standar Proses Pendidikan. Jakarta: Kencana.

Setyosari, P. (2007). Pembelajaran Sistem Online: Tantangan dan Rangsangan. Jurnal Majalah Ilmiah Pembelajaran, 4(2), 1-10.

Supriani, Y., Fardillah, F., Turmudi, T., \& Herman, T. (2019). Developing Students' Mathematical Justification Skill Through Experiential Learning. Journal of Physics: Conference Series, 1179(1), 1-6. Doi : https://doi.org/10.1088/1742$\underline{6596 / 1179 / 1 / 012070}$

Supriani, Y. \& Sholahudin, U. (2019). Mengembangkan Kemampuan Memformulasikan Konjektur Siswa melalui Experiental Learning. Jurnal Kajian Pendidikan Matematika, 4(2), 173-178. Doi : http://dx.doi.org/10.30998/jkpm.v4i2.3885

Vygotsky, L. S. (1962). Thought and language (E. Hanf-Mann \& G. Vakar, Trans.) Cambridge, MA: MIT Press. 